\title{
Effects of fertilization methods in wheat on gases emission and environmental benefit in Mollisols of Northeast China
}

\author{
Chunzhu Liu \\ Northeast Agricultural University \\ Zhu Yingxue \\ Northeast Agricultural University \\ Qi Wang \\ Northeast Agricultural University \\ Lianzhou Xu \\ Northeast Agricultural University \\ Xianfa Ma ( $\nabla$ xianfa.ma@neau.edu.cn ) \\ Northeast Agricultural University
}

\section{Research Article}

Keywords: Organic substitution, Fertilization by stages, $\mathrm{NH} 3$ volatilization, $\mathrm{N} 2 \mathrm{O}$ and $\mathrm{CO} 2$ emission, Soil enzyme activity

Posted Date: January 18th, 2022

DOI: https://doi.org/10.21203/rs.3.rs-1154740/v1

License: (c) (i) This work is licensed under a Creative Commons Attribution 4.0 International License. Read Full License 


\section{Abstract}

Aims Many previous studies have focused on crop yields, but there is a knowledge gap regarding the environmental benefits of phased fertilization and organic substitution. To study the effects of phased fertilization and organic substitution on soil gas emissions and spring wheat yields, a field experiment was conducted using Mollisols.

Methods Five treatments were set up: conventional nitrogen application (CF); no nitrogen application (N0); one-time (N1), two-stage (N2) and three-stage (N3) application of chemical nitrogen based on $25 \%$ of chemical nitrogen being replaced by organic fertilizer. The changes in $\mathrm{NH}_{3}$ volatilization, $\mathrm{N}_{2} \mathrm{O}$ and $\mathrm{CO}_{2}$ emissions, soil-related carbon and nitrogen invertase activities and soil carbon and nitrogen contents under different treatments were analyzed and compared.

Result The results showed that $\mathrm{N} 1$ had the best emission reduction and yield increase effects. Compared with $\mathrm{CF}, \mathrm{N} 1$ reduced $\mathrm{NH}_{3}$ volatilization, $\mathrm{N}_{2} \mathrm{O}$ and $\mathrm{CO}_{2}$ emissions accumulation by $28.94 \%, 10.29 \%$ and $17.21 \%$, respectively, and increased spring wheat yield by $21.33 \%$. Compared with N2 and N3, N1 could better reduce soil urease, nitrate reductase, catalase and $\beta$-glucosidase activities, reduce the conversion rate of urea and organic carbon, increase the content of $\mathrm{NH}_{4}{ }^{+}-\mathrm{N}$ in soil, and reduce the $\mathrm{NH}_{3}$ volatilization rate and $\mathrm{N}_{2} \mathrm{O}$ and $\mathrm{CO}_{2}$ emissions rates.

Conclusions Comprehensive analysis showed that the $\mathrm{N} 1$ treatment had the best effect on reducing the soil gas emission rate, emission reduction rate and environmental cost as well as on increasing yield.

\section{Introduction}

Wheat is one of the top three crops worldwide, and nitrogen is one of the most restrictive nutrients for wheat production. Increasing the nitrogen application rate within a certain range can improve wheat yield (Herrera et al., 2016; Wen et al., 2019). Although high nitrogen fertilizer inputs can ensure crop yield, the nitrogen use efficiency in China is only approximately 30\% (Lasisi et al., 2021). Due to the excessive application of chemical fertilizers, the traditional fertilization mode in agricultural production has increased $\mathrm{NH}_{3}$ volatilization and emissions of greenhouse gases such as $\mathrm{N}_{2} \mathrm{O}$ and $\mathrm{CO}_{2}$ and reduced nitrogen use efficiency (Huang et al., 2016; Wang et al., 2014). Studies have found that nitrogen loss from $\mathrm{NH}_{3}$ volatilization accounts for approximately $15 \%$ of the amount of fertilizer used, while this proportion is only $7 \%$ in developed countries but $18 \%$ in China, far higher than the world average (Rakshit et al., 2015). Moreover, the application of chemical fertilizers generally increases $\mathrm{N}_{2} \mathrm{O}$ and $\mathrm{CO}_{2}$ emissions (Rosa et al., 2018; Zamanian et al., 2018). Overall, direct and indirect $\mathrm{N}_{2} \mathrm{O}$ emissions from agricultural soils account for more than $50 \%$ of global anthropogenic $\mathrm{N}_{2} \mathrm{O}$ emissions (Lan et al., 2020). In addition, $\mathrm{N}_{2} \mathrm{O}$ can be indirectly generated by $\mathrm{NH}_{3}$ through atmospheric transport and deposition processes (Hayes et al., 2019; Min et al., 2021). $\mathrm{N}_{2} \mathrm{O}$ is an important regulated greenhouse gas, second only to $\mathrm{CO}_{2}$ and $\mathrm{CH}_{4}$ in the atmosphere, and its potential to increase global temperature is very high. The 100-year warming potential of $\mathrm{N}_{2} \mathrm{O}$ was nearly 300 times higher than that of $\mathrm{CO}_{2}$ and 10 times higher than that of $\mathrm{CH}_{4}$ (Lan et al., 2020). As one of the important branches of soil $\mathrm{CO}_{2}$ emissions from terrestrial ecosystems (Bradford et al., 2016), soil $\mathrm{CO}_{2}$ emissions from farmland ecosystems have a huge impact on global carbon emissions (Liu et al., 2018). Therefore, to achieve low-emission agricultural production, it is necessary to further study the effects of proper farming methods on gaseous nitrogen $\left(\mathrm{NH}_{3}\right.$ and $\left.\mathrm{N}_{2} \mathrm{O}\right)$ and gaseous carbon $\left(\mathrm{CO}_{2}\right)$ emissions from farmland soil.

Replacement of chemical fertilizer with organic fertilizer and phased fertilization by stages are important measures to reduce the amounts of chemical fertilizers applied. Replacing chemical fertilizer with organic fertilizer can effectively avoid soil acidification and improve soil nutrient contents and soil enzyme activities (Okami et al., 2016). Fertilization by stages can significantly improve the fertilizer utilization rate and increase crop yield (Zhou et al., 2017). The combined application of organic and inorganic fertilizers can not only increase wheat yield but also improve soil physical and chemical properties and significantly enhance nitrogen fertilizer use efficiency (Xia et al., 2017; Zhao et al., 2016). Replacing chemical fertilizers with organic fertilizers is an important method to reduce $\mathrm{NH}_{3}$ volatilization (Ti et al., 2019). Studies have shown that in winter wheat and summer maize planting, appropriate replacement of chemical with organic fertilizer can significantly reduce $\mathrm{NH}_{3}$ volatilization and $\mathrm{N}_{2} \mathrm{O}$ emissions but increase $\mathrm{CO}_{2}$ emissions (Wang et al., 2018; Zhou et al., 2011). Organic fertilizer can improve soil microbial content and soil enzyme activity. Soil enzyme activity is significantly correlated with carbon and nitrogen transformation. Urease and nitrate 
reductase are important invertases of soil nitrogen, and $\beta$-glucosidase is an important invertase of the soil carbon cycle (Sinsabaugh et al., 2012). Studies have shown that compared with cellulase activity, an increase in ligninase activity can better catalyze the degradation of chemical refractory carbon in soil (Chen et al., 2020).

Northeast China is an important grain production area. As farmers seemingly neglected the ecological environment and paid more attention to yield and efficiency, they blindly pursued yields in agricultural production and overinvested in chemical fertilizers such as urea, which caused environmental pollution. In this study, spring wheat fields were taken as the study object, and chemical nitrogen fertilizer was applied in stages while replacing part of the chemical fertilizer with organic fertilizer in accordance with the conventional tillage mode and fertilizer dosage in agricultural production in Heilongjiang Province. The objectives of this study were to (i) evaluate different fertilization modes optimize a fertilization mode for agricultural production in northeast China that can reduce environmental pollution, and (ii) explore the effects of phased chemical fertilizer application on soil $\mathrm{NH}_{3}$ volatilization, $\mathrm{N}_{2} \mathrm{O}$ and $\mathrm{CO}_{2}$ emissions and soil enzyme activities when replacing $25 \%$ chemical nitrogen fertilizer with organic fertilizer.

\section{Materials And Methods}

\section{Experimental site and soil description}

The field experiments were carried out at the Northeast Agricultural University Experiment Station, Heilongjiang Province, P. R. China ( $\left.45^{\circ} 773^{\prime} \mathrm{N}, 126^{\circ} 938^{\prime} \mathrm{E}\right)$. The site belongs to a typical temperate continental monsoon climate and the average annual temperature is $3.7^{\circ} \mathrm{C}$. The annual precipitation is $500 \mathrm{~mm}$. The soil is a typical black soil. The surface soil properties $(0-20 \mathrm{~cm})$ before the beginning of the experiment were as follows: $\mathrm{pH} 6.87$, total $\mathrm{N} 1.7 \mathrm{~g} \mathrm{~kg}^{-1}$, soil organic matter $25.3 \mathrm{~g} \mathrm{~kg}^{-1}$, ammonium nitrogen $\left(\mathrm{NH}_{4}{ }^{+}-\mathrm{N}\right) 5.55 \mathrm{mg} \mathrm{kg}^{-1}$, nitrate nitrogen $\left(\mathrm{NO}_{3}{ }^{-} \mathrm{N}\right) 5.85 \mathrm{mg} \mathrm{kg}^{-1}$, alkali-hydrolyzale nitrogen $149.25 \mathrm{mg} \mathrm{kg}^{-1}$, Olsen-P 53.01 $\mathrm{mg} \mathrm{kg}^{-1}$, and available potassium $198.81 \mathrm{mg} \mathrm{kg}^{-1}$.

\section{Experimental design and treatments}

The experiment was divided into five treatments: (1) CF: conventional fertilization; (2) N0: no nitrogen fertilizer, while the amount of phosphorus and potassium was the same as in the CF treatment; (3) N1: $25 \%$ of chemical nitrogen fertilizer was replaced by organic fertilizer, while the amount of phosphorus and potassium was the same as in the CF treatment and all fertilizer was applied before sowing; (4) N2: $25 \%$ of chemical nitrogen fertilizer was replaced by organic fertilizer, while the amount of phosphorus and potassium was the same as that in the CF treatment, with $2 / 3$ of chemical nitrogen fertilizer applied before sowing and 1/3 at the jointing stage; (5) N3: $25 \%$ of chemical nitrogen fertilizer was replaced by organic fertilizer, while the amount of phosphorus and potassium was the same as in the CF treatment, $1 / 3$ of chemical nitrogen fertilizer was applied before sowing, and at the jointing and booting stages. Each treatment was repeated three times. The nutrient contents of the conventional fertilizer treatment were $75 \mathrm{~kg} \mathrm{~N} \mathrm{ha}^{-1}, 75 \mathrm{~kg} \mathrm{P}_{2} \mathrm{O}_{5}$ ha $^{-1}$ and $37.5 \mathrm{~kg} \mathrm{~K}_{2} \mathrm{O}$ ha ${ }^{-1}$, and the total application rates of $\mathrm{P}_{2} \mathrm{O}_{5}$ and $\mathrm{K}_{2} \mathrm{O}$ in each fertilizer treatment were consistent with those in the conventional fertilizer treatment.

The spring wheat variety Kechun-9 was selected in this experiment. The plot area was $2.4 \mathrm{~m} \times 8.0 \mathrm{~m}=19.2 \mathrm{~m}^{2}$. The seeds were sown on April 9, 2020, with chemical and organic fertilizer applied as basal fertilizers. The depth of seeding and fertilizer application was $5 \mathrm{~cm}$, and the wheat density was 6.5 million $\mathrm{hm}^{-2}$ plants. Chemical fertilizer consisted of urea ( $\left.\mathrm{N}, 46.0 \%\right)$, calcium superphosphate $\left(\mathrm{P}_{2} \mathrm{O}_{5}, 46 \%\right)$ and potassium chloride $\left(\mathrm{K}_{2} \mathrm{O}, 60 \%\right)$, and a commercial organic fertilizer was used $\left(\mathrm{N}-\mathrm{P}_{2} \mathrm{O}-\mathrm{K}-\mathrm{K}_{2} \mathrm{O}, 2.33-1.8-2.35\right.$; organic matter, 46.1\%). The fertilizer dosage for the spring wheat growing season is shown in Table 1. 
Table 1

The schedule of fertilization during wheat growing season $\left(\mathrm{kg} \mathrm{ha}^{-1}\right)$

\begin{tabular}{|c|c|c|c|c|c|c|}
\hline \multirow[t]{2}{*}{ Treatment } & \multicolumn{4}{|l|}{ Before sowing } & \multirow{2}{*}{$\begin{array}{l}\text { Jointing stage } \\
\text { Urea }\end{array}$} & \multirow{2}{*}{$\begin{array}{l}\text { Booting stage } \\
\text { Urea }\end{array}$} \\
\hline & Organic Fertilizer & Urea & Triple superphosphate & Potassium chloride & & \\
\hline $\mathrm{CF}$ & - & 163 & 163 & 63 & - & - \\
\hline NO & - & - & 163 & 63 & - & - \\
\hline N1 & 805 & 123 & 131 & 31 & - & - \\
\hline N2 & 805 & 82 & 131 & 31 & 41 & - \\
\hline N3 & 805 & 41 & 131 & 31 & 41 & 41 \\
\hline
\end{tabular}

\section{Calculation of cumulative soil $\mathrm{NH}_{3}, \mathrm{~N}_{2} \mathrm{O}$ and $\mathrm{CO}_{2}$ emissions}

The $\mathrm{NH}_{3}$ volatilization flux was measured by the boric acid absorption-continuous airflow sealing method, $\mathrm{N}_{2} \mathrm{O}$ and $\mathrm{CO}_{2}$ were collected by the static incubator method, and the concentrations of $\mathrm{N}_{2} \mathrm{O}$ and $\mathrm{CO}_{2}$ were analyzed by gas chromatography (Shang et al., 2014). During the test, an airtight chamber made of polyvinyl chloride (PVC, diameter $16 \mathrm{~cm}$, height $16 \mathrm{~cm}, 5 \mathrm{~cm}$ into the ground, with an air extraction device attached to the top of the chamber) was inserted into the test area to measure $\mathrm{NH}_{3}$ volatilization and $\mathrm{N}_{2} \mathrm{O}$ and $\mathrm{CO}_{2}$ emissions. The temperature and air temperature in the closed chamber were measured with a thermometer at the same time the gas samples were collected: three days after seeding and fertilization (April 11, SD-1), 8 days after seeding (April 16, SD-2), at the wheat seedling stage (May 1, SS), before the jointing stage fertilization (June 2, JS-1), after the jointing stage fertilization (June 7, JS-2), before the booting stage fertilization (July 3, BS-1) and after the booting stage fertilization (on July 9, BS-2).

Calculation formula of $\mathrm{NH}_{3}$ volatilization rate:

$v=M \times A^{-1} \times D^{-1} \times 10^{-2}(1)$

$\mathrm{U}$ is the volatilization rate of $\mathrm{NH}_{3}-\mathrm{N}\left(\mathrm{kg} \mathrm{ha}^{-1} \mathrm{~d}^{-1}\right)$; $\mathrm{M}$ is the ammonia quantity $\left(\mathrm{NH}_{3}-\mathrm{N}, \mathrm{mg}\right)$ measured each time by a single device of the closed method; $A$ is the cross-sectional area $\left(\mathrm{m}^{2}\right)$ of the capturing device; $D$ is the time of each successive capture (d).

Calculation formula of $\mathrm{N}_{2} \mathrm{O}$ and $\mathrm{CO}_{2}$ emission fluxes:

$F=M \times \rho \times(K+T)^{-1} \times H \times R^{-1} \times(d c / d t)(2)$

$F$ is the emission flux $\left(\mu \mathrm{g} \mathrm{m}^{-2} \mathrm{~h}^{-1}\right), M$ is the molar mass of carbon $\left(12 \mathrm{~g} \mathrm{~mol}^{-1}\right), \rho$ is the density of $\mathrm{N}_{2} \mathrm{O}\left(\mathrm{g} \mathrm{L}^{-1}\right), H$ is the height of the collection box $(\mathrm{cm}), R$ is the universal gas constant $\left(8.314 \mathrm{~J} \mathrm{~mol}^{-1} \mathrm{k}^{-1}\right), K$ is the standard temperature $(\mathrm{K}), T$ is the average temperature in the chamber at the time of sampling $\left({ }^{\circ} \mathrm{C}\right)$, and $d c / d t$ is the $\mathrm{N}_{2} \mathrm{O}$ emission rate $\left(\mu \mathrm{L} \mathrm{L}^{-1} \mathrm{~min}^{-1}\right)$.

Calculating formula of $\mathrm{NH}_{3}, \mathrm{~N}_{2} \mathrm{O}$ and $\mathrm{CO}_{2}$ emission accumulation:

$M a=0.5 \times\left(F i+F_{i+1}\right) \times n(3)$

The cumulative emission of soil $\mathrm{NH}_{3}, \mathrm{~N}_{2} \mathrm{O}$ and $\mathrm{CO}_{2}$ ( $\mathrm{t} \mathrm{ha}^{-1}$ ) were denoted by $M_{a}$, where the emission of soil $\mathrm{NH}_{3}, \mathrm{~N}_{2} \mathrm{O}$ and $\mathrm{CO}_{2}$ is presented by Fiat initial time; and the emission of soil $\mathrm{NH}_{3}, \mathrm{~N}_{2} \mathrm{O}$ and $\mathrm{CO}_{2}$ is presented by $F_{i+1}$ after the following time i; $\mathrm{n}$ is the number of interval days for soil $\mathrm{NH}_{3}, \mathrm{~N}_{2} \mathrm{O}$ and $\mathrm{CO}_{2}$ emission.

Gas emission coefficient calculation formula:

$\rho=\left(M_{N}-M_{N O}\right) / 163 \times 100 \%(4)$

$\rho$ is the gas emission coefficient; $M_{N}$ is the cumulative amount of gas volatilization under different treatments; $M_{N o}$ is the volatile accumulation of blank treatment gas.

Calculation formula of gas emission reduction ratio: 
$R=\left(M_{C F}-M_{N}\right) /\left(M_{C F}-M_{N O}\right) \times 100 \%(5)$

$R$ is the proportion of gas emission reduction; $M_{C F}$ is the cumulative emission of gas volatilization from conventional treatment. $M_{N}$ is the cumulative emissions of gas volatilization from other fertilization treatments. $M_{N o}$ is the cumulative emission of volatilization of blank treatment gas.

The calculation formula of environmental loss benefit caused by gas volatilization:

$E C=M \times D C(6)$

$E C$ is environmental loss, Yuan ha ${ }^{-1} ; M$ is the accumulation of soil gas volatilization, $\mathrm{kg} \mathrm{ha}^{-1} ; D C$ is the environmental loss of gas volatilization, $\mathrm{NH}_{3}$ is 37.5 Yuan $\mathrm{kg}^{-1}, \mathrm{~N}_{2} \mathrm{O}$ is $310 \times 0.4$ Yuan kg $^{-1}, \mathrm{CO}_{2}$ is 0.4 Yuan kg-1 (Gu et al., 2012; Li et al., 2021).

\section{Soil Sampling and Analysis}

Soil samples were collected at the seedling stage (May 1, SS), jointing stage (June 7, JS), booting stage (July 9, BS) and maturity stage (July 28, MP). Soil samples from the 0-10 cm layer were collected with a soil drill, and 5 points were taken and evenly mixed to form a composite soil sample. Some of the fresh samples were stored, and the contents of $\mathrm{NH}_{4}{ }^{+}$and $\mathrm{NO}_{3}{ }^{-}$in the soil were determined by $0.01 \mathrm{~mol} \mathrm{~L}^{-1} \mathrm{CaCl}_{2}$ and flow analysis. Some samples were dried, ground and screened, and $\mathrm{pH}$, organic matter and total nitrogen were determined according to conventional soil agrochemical laboratory methods. Urease was determined by the phenol-sodium hypochlorite colorimetric method, nitrate reductase was determined by the phenol-disulfonic acid colorimetric method, $\beta$-glucosidase was determined by the $\mathrm{p}$-nitrophenol colorimetric method, and catalase was determined by the potassium permanganate titration method (Mei et al., 2020; Saiya et al., 2002).

The apparent soil nitrification rate (SNR) was calculated according to the following equation:

$S N R=A /(A+B) \times 100 \%$

where $\mathrm{A}$ indicates the concentrations of $\mathrm{NO}_{3}{ }^{-}$in the surface soil after different fertilizer applications, and $\mathrm{B}$ indicates the concentrations of $\mathrm{NH}_{4}{ }^{+}$in the surface soil after different fertilizer applications.

Crop yield

At the mature stage, a $0.9 \mathrm{~m}^{2}$ quadrat (3 rows and 2 meters) was randomly selected from each plot to calculate the planting density. The aboveground plant parts were collected and put into nylon net bags, dried naturally and threshed for yield measurement.

\section{Data analysis}

Excel 2010 software was used for data calculation. SPSS 20.0 software was used for single factor analysis of variance (LSD) among all processes at the 0.05 probability level. The figures were plotted by software Origin 2019b.

\section{Results}

Soil $\mathrm{NH}_{3}$ volatilization

As shown in Fig. 1, in general, the $\mathrm{NH}_{3}$ volatilization rate decreased significantly from fertilization at the seeding stage to the jointing stage, and the $\mathrm{NH}_{3}$ volatilization rate of the $\mathrm{N} 1$ treatment was significantly lower than that of the $\mathrm{CF}$ treatment during the wheat growth stage $(P<0.05)$. Staging fertilizer applications reduced the $\mathrm{NH}_{3}$ volatilization rate before the jointing stage but significantly increased the $\mathrm{NH}_{3}$ volatilization rate under the $\mathrm{N} 2$ treatment after the jointing stage and under the $\mathrm{N} 3$ treatment at the jointing stage. The volatilization accumulation of $\mathrm{NH}_{3}$ in the $\mathrm{CF}$ treatment was significantly higher than that in the organic replacement treatments, and $\mathrm{NH}_{3}$ volatilization from the fertilization to seedling stages accounted for the largest proportion of the total accumulation. Compared with the CF treatment, the $\mathrm{N} 1, \mathrm{~N} 2$ and $\mathrm{N} 3$ treatments reduced $\mathrm{NH}_{3}$ emission accumulation by $28.94 \%, 19.63 \%$ and $19.70 \%$, respectively. Compared with the N1, N2 and N3 treatments, fertilization at different stages reduced 
$\mathrm{NH}_{3}$ emission accumulation at the seedling stage, but fertilization at different stages significantly increased $\mathrm{NH}_{3}$ emission accumulation at the jointing stage and booting stage, so the $\mathrm{N} 1$ treatment had the lowest $\mathrm{NH}_{3}$ emission accumulation.

Soil $\mathrm{N}_{2} \mathrm{O}$ emissions

As shown in Fig. 2, the $\mathrm{N}_{2} \mathrm{O}$ emission rate was the highest after fertilization at the seeding stage and decreased significantly from the fertilization to the jointing stage. In general, the $\mathrm{N}_{2} \mathrm{O}$ emission rate of the $\mathrm{CF}$ and $\mathrm{N} 1$ treatments decreased gradually during the growth stages of wheat. The $\mathrm{N}_{2} \mathrm{O}$ emission rate before the jointing stage was decreased by applying chemical fertilizer in stages, but the $\mathrm{N}_{2} \mathrm{O}$ emission rate at the jointing stage and under the $\mathrm{N} 3$ treatment after fertilization at the jointing and booting stages was significantly increased. The $\mathrm{N}_{2} \mathrm{O}$ emission accumulation under the $\mathrm{CF}$ treatment was significantly higher than that under the other treatments, and the $\mathrm{N}_{2} \mathrm{O}$ emissions from the fertilization to seeding stages accounted for the largest proportion of the total accumulated. Compared with that under $\mathrm{CF}$, the accumulation of $\mathrm{N}_{2} \mathrm{O}$ emissions under $\mathrm{N} 1, \mathrm{~N} 2$ and N3 decreased by $10.29 \%$, $11.52 \%$ and $16.87 \%$, respectively. Compared with the N1 treatment with one-time fertilization, the N2 and N3 treatments with phased fertilization significantly reduced $\mathrm{N}_{2} \mathrm{O}$ emissions at the seeding stage, but they did not significantly increase $\mathrm{N}_{2} \mathrm{O}$ emissions at the jointing and booting stages, so the accumulation of $\mathrm{N}_{2} \mathrm{O}$ emissions under the $\mathrm{N} 1$ treatment was higher than that under the N2 and N3 treatments.

Soil $\mathrm{CO}_{2}$ emissions

As shown in Fig. 3, during the growth stage, the $\mathrm{CO}_{2}$ emission rate under the $\mathrm{N} 1$ treatment was significantly lower than that under the $\mathrm{CF}$ treatment. The staged application of chemical fertilizer reduced the $\mathrm{CO}_{2}$ emission rate before the jointing stage but significantly increased the $\mathrm{CO}_{2}$ emission rate under the $\mathrm{N} 2$ treatment after the jointing stage and under the N3 treatment at the jointing stage. The $\mathrm{CO}_{2}$ emission accumulation of the $\mathrm{CF}$ treatment was significantly higher than that of the other treatments, and

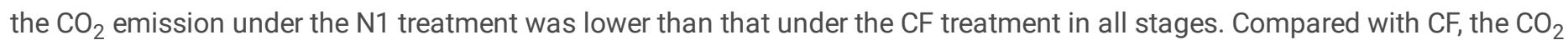
emission accumulation under the N1, N2 and N3 treatments decreased by $17.21 \%, 7.27 \%$ and $11.74 \%$, respectively. Compared with $\mathrm{N} 1, \mathrm{~N} 2$ and $\mathrm{N} 3$, which employed phased fertilization could reduce $\mathrm{CO}_{2}$ emission accumulation from the seedling stage to the jointing stage, but phased fertilization could significantly increase $\mathrm{CO}_{2}$ emission accumulation at the jointing stage and booting stage, so the $\mathrm{N} 1$ treatment resulted in the lowest $\mathrm{CO}_{2}$ emission accumulation.

\section{Soil $\mathrm{pH}, \mathrm{SOC}$, total $\mathrm{N}, \mathrm{NH}_{4}{ }^{+}-\mathrm{N}$ and $\mathrm{NO}_{3}{ }^{-}-\mathrm{N}$ contents}

Soil fertility is one of the important factors affecting crop yield, and soil pH, organic matter, total nitrogen, ammonium nitrogen and nitrate nitrogen contents are important indexes to measure soil fertility. As shown in Fig. 4, the application of organic fertilizer increased the soil total nitrogen content but had no significant effect on the soil organic matter and $\mathrm{pH}$. Compared with the $\mathrm{CF}$ treatment, the $\mathrm{N} 1$ treatment had the best effect on increasing soil nitrogen nutrients. Applying chemical nitrogen fertilizer by stages improved the soil nitrogen nutrient content at the later growth stage of wheat but decreased the soil nitrogen nutrient content at the seedling stage and jointing stage of wheat. The application of organic fertilizer can increase the content of available nutrients in soil, and the content of ammonium and nitrate nitrogen in soil may be significantly improved. Compared with the N2 and N3 treatments, the $\mathrm{N} 1$ treatment had a better effect on increasing the ammonium nitrogen and nitrate nitrogen contents.

The SNR value under the N1 treatment was the lowest at all stages and was significantly lower than that under the N0 and CF treatments (Table 2; $P<0.05$ ). The N1, N2 and N3 treatments were superior to the NO and CF treatments in inhibiting $\mathrm{NH}_{4}{ }^{+}$to $\mathrm{NO}_{3}{ }^{-}$ transformation. The maximum value of $\mathrm{NH}_{4}{ }^{+} / \mathrm{NO}_{3}{ }^{-}$appeared in the jointing stage under the $\mathrm{NO}$ treatment and was significantly higher than that of the $\mathrm{NO}$ and $\mathrm{CF}$ treatments (Table 2; $P<0.05$ ). $\mathrm{NH}_{4}{ }^{+} / \mathrm{NO}_{3}{ }^{-}$under the $\mathrm{N} 3$ treatment was significantly increased by $80.9 \%$ and $130.3 \%$ at the jointing and booting stages, respectively. In general, with the growth of wheat, the value of $\mathrm{NH}_{4}{ }^{+} / \mathrm{NO}_{3}{ }^{-}$ decreased under urea application alone. The $\mathrm{NH}_{4}{ }^{+} / \mathrm{NO}_{3}{ }^{-}$value could be increased by applying organic fertilizer and by phased fertilization at different periods. 
Table 2

The SNR and $\mathrm{NH}_{4}{ }^{+} / \mathrm{NO}_{3}{ }^{-}$as affected by the application of Substitute organic fertilizer for chemical fertilizer and stage fertilization. Different lowercase letters in the same column indicate a significant difference between treatments at $P<0.05$ level.

\begin{tabular}{|c|c|c|c|c|c|c|c|c|}
\hline \multirow[t]{2}{*}{ Treatment } & \multicolumn{4}{|l|}{ SNR(\%) } & \multicolumn{4}{|l|}{$\mathrm{NH}_{4}^{+} / \mathrm{NO}_{3}^{-}$} \\
\hline & SS & JS & BS & MP & SS & JS & BS & MP \\
\hline $\mathrm{CF}$ & $71.7 \pm 2.9 a$ & $16.1 \pm 1.4 b$ & $22.4 \pm 5.1 \mathrm{a}$ & $22.7 \pm 0.8 b$ & $0.40 \pm 0.06 c$ & $5.23 \pm 0.53 a b$ & $3.58 \pm 1.04 a$ & $3.40 \pm 0.16 \mathrm{ab}$ \\
\hline NO & $78.4 \pm 1.1 a$ & $12.3 \pm 2.6 b$ & $25.7 \pm 5.6 a$ & $34.5 \pm 6.6 a$ & $0.28 \pm 0.02 c$ & $7.34 \pm 1.76 a$ & $2.98 \pm 0.86 a$ & $1.96 \pm 0.56 c$ \\
\hline N1 & $36.2 \pm 2.5 c$ & $19.8 \pm 0.9 b$ & $25.9 \pm 4.6 a$ & $19.6 \pm 0.8 b$ & $1.77 \pm 0.19 a$ & $4.05 \pm 0.22 b c$ & $2.92 \pm 0.69 a$ & $4.12 \pm 0.20 \mathrm{a}$ \\
\hline N2 & $53.1 \pm 0.5 b$ & $38.4 \pm 1.8 \mathrm{a}$ & $32.8 \pm 2.5 \mathrm{a}$ & $21.5 \pm 1.9 b$ & $0.89 \pm 0.02 b$ & $1.61 \pm 0.12 d$ & $2.05 \pm 0.23 a$ & $3.67 \pm 0.42 \mathrm{ab}$ \\
\hline N3 & $73.4 \pm 5.5 a$ & $34.8 \pm 5.5 a$ & $32.2 \pm 6.6 a$ & $27.3 \pm 5.3 a b$ & $0.37 \pm 0.10 c$ & $1.91 \pm 0.46 \mathrm{~cd}$ & $2.21 \pm 0.75 a$ & $2.75 \pm 0.67 \mathrm{bc}$ \\
\hline
\end{tabular}

Note: SS, seeding stage; JS, jointing stage; BS, booting stage; MP, mature stage.

\section{Discussion}

\section{Soil $\mathrm{NH}_{3}$ volatilization}

In this study, compared with conventional fertilization, replacing $25 \%$ of chemical fertilizer with organic fertilizer can reduce the emission rates and amounts of $\mathrm{NH}_{3}$ and $\mathrm{N}_{2} \mathrm{O}$, mainly because a large number of organic acids are generated during the decomposition of organic fertilizer. Organic acids can reduce soil $\mathrm{pH}$ and increase the soil retention of $\mathrm{NH}_{4}{ }^{+}$, and the volatilization rate and volatilization accumulation of $\mathrm{NH}_{3}$ are reduced (Liang et al., 2012; Pant et al., 2017). After fertilization at the sowing stage, the $\mathrm{NH}_{3}$ volatilization rate in the treatments with staged fertilization was lower than that in the one-time fertilization treatment, but the volatilization peak appeared at the jointing and booting stages, and the emission peak showed a decreasing trend. This is because the input of exogenous nitrogen promoted the process of soil denitrification, and a large amount of $\mathrm{NH}_{3}$ was generated in a short time (Vinzent et al., 2017). Rational application of organic fertilizer significantly enhances soil carbon and nitrogen conversion capacity and enzyme activity (Liu et al., 2018; Okami et al., 2016), as shown in Fig. 5. This study found that replacement of $25 \%$ of chemical nitrogen with organic fertilizer treatments significantly increased the contents of ammonium nitrogen and nitrate nitrogen in soil because organic fertilizer increased the number and activity of soil microorganisms and soil enzymes, promoted nitrogen transformation, and was conducive to the transformation of soil nitrogen into forms that can be absorbed and utilized by plants. In this study, the content of ammonium nitrogen in soil under the N1, N2 and N3 treatments was generally higher than that of nitrate nitrogen at the harvest stage because the organic substances contained in the organic fertilizer could adsorb $\mathrm{NH}_{4}{ }^{+}$in soil, thus slowing nitrification of $\mathrm{NH}_{4}{ }^{+}$(Thomsen et al., 1998), reducing $\mathrm{NH}_{3}$ volatilization and increasing the $\mathrm{NH}_{4}{ }^{+}$content in soil. This is beneficial to the absorption and utilization of nitrogen in spring wheat and increases yield.

Urease is an important soil hydrolase that catalyzes the hydrolysis of urea and organic fertilizer to produce $\mathrm{NH}_{3}, \mathrm{~N}_{2} \mathrm{O}$ and $\mathrm{CO}_{2}$ (Hagin et al., 1990). After hydrolysis, $\mathrm{NH}_{4} \mathrm{HCO}_{3}$ is rapidly transformed into $\mathrm{NH}_{4}{ }^{+}-\mathrm{N}$ and $\mathrm{HCO}_{3}{ }^{-}$, part of which is absorbed by the soil as adsorbed $\mathrm{NH}_{4}{ }^{+}$, and the other part enters the soil solution to rapidly improve the concentration of $\mathrm{NH}_{4}{ }^{+}$and $\mathrm{HCO}_{3}{ }^{-}$in the soil, providing sufficient substrates for $\mathrm{NH}_{3}$ volatilization and $\mathrm{CO}_{2}$ emission. In this study, the soil urease activity was lower under organic than under conventional fertilization treatment, because reducing the urea content in soil reduces urea hydrolysis to produce nitrogen, and when the nitrogen needed for soil microbes is adequate, soil microbial activity changes, indirectly changing soil urease activity (Chen et al., 2017; Liu et al., 2017). As shown in the heat analysis in Fig. 5, N1 promoted urease activity more than N2 and N3, with higher urease activity at the booting stage than at the jointing stage; this is because the organic fertilizer promoted the stable and sustained release of nitrogen in the soil, providing an ample nitrogen source for microbial activity, and chemical fertilizers increased the nitrogen loss in stages, failing to provide nutrients in time. 
Under the action of soil urease, urea is hydrolyzed into $\mathrm{NH}_{4} \mathrm{HCO}_{3}$ and then rapidly transformed into $\mathrm{NH}_{4}{ }^{+}-\mathrm{N}$. Part of the urea is absorbed by the soil colloids as adsorbed $\mathrm{NH}_{4}{ }^{+}$, and the other part enters the soil solution so that the concentration of $\mathrm{NH}_{4}{ }^{+}$ increases rapidly, providing sufficient substrate for ammonia volatilization. However, a large number of organic nitrogen components in organic fertilizer can participate in the process of $\mathrm{NH}_{3}$ volatilization only after a long time of mineralization and decomposition (Shan et al., 2015). In addition, organic matter will release a large number of organic acids and form humus during the decomposition process, which inhibits the increase in soil $\mathrm{pH}$ during urea hydrolysis. Thus, $\mathrm{NH}_{3}$ volatilization in soil was significantly inhibited.

\section{Soil $\mathrm{N}_{2} \mathrm{O}$ emissions}

In this study, the treatments in which organic fertilizer replaced chemical fertilizer significantly reduced $\mathrm{N}_{2} \mathrm{O}$ emissions because organic matter consumes oxygen in soil during microbial decomposition, inhibits nitrification, and thus reduces the release of $\mathrm{N}_{2} \mathrm{O}$ in soil. In this study, the soil nitrate nitrogen content of the CF, N2 and N3 treatments was higher than that of ammonium nitrogen at the jointing stage, which might have been due to the transformation of $\mathrm{NH}_{4}{ }^{+}$into $\mathrm{NO}_{3}{ }^{-}$under the action of nitrifying microorganisms, which would also lead to an increase in $\mathrm{N}_{2} \mathrm{O}$ emissions. As shown in Fig. 6, the positive effects on nitrate reductase activity were $\mathrm{N} 1>\mathrm{N} 2>\mathrm{CK}>\mathrm{N} 3$ in this study, which may have been due to the organic $\mathrm{C} / \mathrm{N}$ value being lower, which is suitable for microbes, than those under the chemical fertilizer (Rashid et al., 2020). The organic fertilizer contained mushroom residue that can more quickly provide soil organic matter, increasing the available substrate for microbes in the soil, while nitrate reductase activity suppresses soil nitrification, and thus $\mathrm{N}_{2} \mathrm{O}$ emissions are reduced. Therefore, soil nitrate reductase activity is significantly positively correlated with $\mathrm{N}_{2} \mathrm{O}$ emissions (Chen et al., 2017; Liu et al., 2017).

In this study, N1 showed the highest nitrate reductase activity in soil, which may have been because the $\mathrm{C} / \mathrm{N}$ value of organic fertilizer was lower than that of the single chemical fertilizer and was suitable for microbial decomposition (Rashid et al., 2020). Moreover, organic fertilizer can provide soil organic matter more quickly than fungal residue, and thus the available substrate of soil microbes increases, and the denitrifying enzyme activity, in particular, nitrate reductase activity, increases (Chen et al., 2014; Elzobair et al., 2016). Soil nitrate reductase decreased gradually with wheat growth, which may have been related to the choice of spring wheat as the experimental object. Spring sowing improves soil aeration, the nitrifying bacteria in the soil increased, and denitrification resulted in the highest nitrate reductase activity in May-June. As temperatures rose gradually, wheat soil water evaporation increased. The suitable soil hydrothermal environment formed in May and June was broken, the metabolic activities of denitrifying microorganisms decreased, and the activity of soil nitrate reductase decreased (Van et al., 2014).

\section{Soil $\mathrm{CO}_{2}$ emissions}

Urease is an important soil hydrolase that catalyzes the hydrolysis of urea and organic fertilizer to produce $\mathrm{CO}_{2}\left(\mathrm{Hagin}_{\mathrm{n}}\right.$ et al., 1990). After hydrolysis, $\mathrm{NH}_{4} \mathrm{HCO}_{3}$ will rapidly transform into $\mathrm{HCO}_{3}{ }^{-}$and enter the soil solution, rapidly increasing the concentration of $\mathrm{HCO}_{3}{ }^{-}$in the soil and providing sufficient substrate for $\mathrm{CO}_{2}$ emission. Urea hydrolysis is the main source of $\mathrm{CO}_{2}$ emissions, while the replacement of chemical fertilizer by organic fertilizer reduces the urea content in soil, so the $\mathrm{CO}_{2}$ emissions under the replacement treatments were significantly reduced. In this study, as shown in Fig. 7, the activities of $\beta$-glucosidase and catalase under the $\mathrm{N} 1$ treatment were higher than those under the other treatments, mainly because organic fertilizer improved soil fertility, and the increase in carbon, nitrogen and oxygen contents promoted the growth of soil microorganisms and the secretion of microbial enzymes and increased the activities of $\beta$-glucosidase and catalase. The application of chemical and organic fertilizers increased the content of organic matter, led to an increase in soil microbial species and number, and increased the activities of hydrolytic enzymes such as $\beta$-glucosidase and catalase, while phased fertilization failed to provide carbon, nitrogen and oxygen in time, so the enzyme activities decreased. Compared with $\beta$-glucoside, catalase was more conducive to the degradation and transformation of soil refractory carbon (Chen et al., 2020). As shown in Fig. 7, N2 and N3 increased soil catalase activity at the later stage of wheat growth, thus improving microbial carbon utilization and transformation and promoting $\mathrm{CO}_{2}$ emissions.

\section{Soil $\mathrm{NH}_{3}, \mathrm{~N}_{2} \mathrm{O}$ and $\mathrm{CO}_{2}$ environmental benefits and wheat yields}


As shown in Table 3, there were significant differences in $\mathrm{NH}_{3}, \mathrm{~N}_{2} \mathrm{O}$ and $\mathrm{CO}_{2}$ emission rates $(\rho)$, emission reduction rates $(\mathrm{R})$ and environmental costs (EC) among the different treatments. The emission rates and environmental costs of $\mathrm{NH}_{3}, \mathrm{~N}_{2} \mathrm{O}$ and $\mathrm{CO}_{2}$ under the CF treatment were the highest. Compared with those of the CF treatment, the $\mathrm{NH}_{3}$ emission rates of N1, $\mathrm{N} 2$ and N3 decreased by $53.56 \%, 36.29 \%$ and $36.50 \%$, respectively, and the $\mathrm{N}_{2} \mathrm{O}$ emission rates decreased by $21.13 \%, 23.94 \%$ and $35.21 \%$, respectively. The $\mathrm{CO}_{2}$ emission rate decreased by $32.76 \%, 13.83 \%$ and $22.36 \%$; the $\mathrm{N} 1$ treatment had the highest emission reduction rates for $\mathrm{NH}_{3}$ and $\mathrm{CO}_{2}$. Compared with $\mathrm{N} 1, \mathrm{~N} 2$ and $\mathrm{N} 3$ reduced the emission reduction rates of $\mathrm{NH}_{3}$ by $32.14 \%$ and $31.90 \%$ and those of $\mathrm{CO}_{2}$ by $57.78 \%$ and $31.75 \%$, respectively. $\mathrm{N} 3$ had the highest $\mathrm{N}_{2} \mathrm{O}$ emission reduction rate. Compared with that of $\mathrm{N} 3$, the $\mathrm{N}_{2} \mathrm{O}$ emission reduction rates of $\mathrm{N} 1$ and $\mathrm{N} 2$ were $38.30 \%$ and $30.45 \%$, respectively. The environmental costs of $\mathrm{NH}_{3}$ in the $\mathrm{N} 1, \mathrm{~N} 2$ and $\mathrm{N} 3$ treatments decreased by $28.94 \%, 19.64 \%$ and $19.71 \%$, the environmental costs of $\mathrm{N}_{2} \mathrm{O}$ decreased by $10.32 \%, 11.64 \%$ and $16.73 \%$, and the environmental costs of $\mathrm{CO}_{2}$ decreased by $17.20 \%, 7.27 \%$ and $11.74 \%$. Compared with $\mathrm{N} 2$ and $\mathrm{N} 3, \mathrm{~N} 1$ had the lowest total environmental cost of gas emissions, with a $9.25 \%$ and $5.46 \%$ reduction in total environmental cost compared with N2 and N3.

Table 3

$\mathrm{NH}_{3}, \mathrm{~N}_{2} \mathrm{O}$ and $\mathrm{CO}_{2}$ average emission rates $(\rho, \%)$, emission reduction rate $(\mathrm{R}, \%)$, environment cost $\left(\mathrm{EC}\right.$, Yuan ha ${ }^{-1}$ ) under different treatments, total environment cost (Total EC, Yuan ha-1) and wheat yield $\left(\mathrm{kg} \mathrm{ha}^{-1}\right)$.

\begin{tabular}{|c|c|c|c|c|c|c|c|c|c|c|c|}
\hline \multirow[t]{2}{*}{ Treatment } & \multicolumn{3}{|l|}{$\mathrm{NH}_{3}$} & \multicolumn{3}{|l|}{$\mathrm{N}_{2} \mathrm{O}$} & \multicolumn{3}{|l|}{$\mathrm{CO}_{2}$} & \multirow[t]{2}{*}{ Total EC } & \multirow[t]{2}{*}{ Yield } \\
\hline & $\rho$ & $\mathbf{R}$ & EC & $\rho$ & $\mathbf{R}$ & $\mathrm{EC}$ & $\rho$ & $\mathbf{R}$ & EC & & \\
\hline $\mathrm{CF}$ & 4.63 & - & 523.63 & 0.71 & - & 301.40 & 515.88 & - & 640.40 & 1465.44 & $4159 \pm 166 b$ \\
\hline NO & - & - & 240.58 & - & - & 157.37 & - & - & 304.05 & 702.00 & $2813 \pm 129 c$ \\
\hline N1 & 2.15 & 53.54 & 372.09 & 0.56 & 21.60 & 270.30 & 346.89 & 32.76 & 530.22 & 1172.60 & $5046 \pm 253 a$ \\
\hline N2 & 2.95 & 36.33 & 420.81 & 0.54 & 24.35 & 266.33 & 444.52 & 13.83 & 593.87 & 1281.02 & $4851 \pm 116 a$ \\
\hline N3 & 2.94 & 36.46 & 420.43 & 0.46 & 35.01 & 250.97 & 400.53 & 22.36 & 565.19 & 1236.59 & $3864 \pm 153 b$ \\
\hline
\end{tabular}

Compared with CF, one-time fertilization and two-stage fertilization based on $25 \%$ of chemical fertilizer being replaced by organic fertilizer can significantly increase the yield of spring wheat by $21.33 \%$ and $16.64 \%$, respectively. One-time fertilization has the best yield increase effect (Table 3) because spring wheat in Northeast China has a short growth period, and its demand for nitrogen is concentrated from the jointing stage to the booting stage (Ladha et al., 2016). The release of nutrients by the organic fertilizer was slow, and the yield of spring wheat in this experiment was N1>N2>N3, further indicating that phased fertilization caused a large amount of nitrogen fertilizer to remain unavailable for too long, resulting in insufficient nitrogen supply in the early spring wheat growth. Compared with that under one-time fertilization, nitrogen use efficiency was reduced, affecting the growth of spring wheat vegetative organs. In this study, replacement of $25 \%$ of chemical fertilizer with slow nitrogen-release organic fertilizer reduced early nitrogen loss, and since spring wheat shows an increased demand for nitrogen in the middle and late growth periods, proper fertilizer staging can more effectively meet the demands for nitrogen for spring wheat growth; thus, two applications significantly increased yields (Redding et al., 2016). However, the N3 treatment, which included substitution with organic fertilizer and application in three stages, decreased yield. This is because fertilizer can be absorbed and utilized by crops only after it is transformed and migrates into the soil. However, multiple spray or broadcast applications of nitrogen fertilizer in a short period of time easily causes fertilizer loss and reduces the fertilizer utilization rate. Therefore, the three-stage fertilization treatment could not supply nitrogen in a timely manner during the most critical stage for plant nutrient absorption (Li et al., 2018; Wang et al., 2018), resulting in a yield reduction in spring wheat.

\section{Conclusions}

Based on soil characteristics and climate conditions in the black soil region of Northeast China, compared with conventional application of chemical fertilizer and staging applications of chemical nitrogen fertilizer while substituting organic fertilizer for $25 \%$ of the chemical nitrogen fertilizer, the one-time fertilization before sowing with a substitution of $25 \%$ of chemical nitrogen with organic fertilizer could effectively improve soil carbon and nitrogen nutrient contents and spring wheat yield; moreover, under this treatment, the activities of urease, nitrate reductase, $\beta$-glucosidase and catalase in soil were decreased, the content of $\mathrm{NH}_{4}{ }^{+}-\mathrm{N}$ in 
soil was increased, the amount of $\mathrm{NH}_{3}$ volatilization, $\mathrm{N}_{2} \mathrm{O}$ and $\mathrm{CO}_{2}$ emissions were significantly reduced, and the economic and environmental benefits were increased.

\section{Declarations}

\section{Acknowledgments}

We thank Meng Qingfeng and Zhao Ying for their technical work during the experiment, Zhao Shuo, Yu Fei and Wang Yong for their help during the harvest, and the soil Physics and Chemistry Laboratory of Northeast Agricultural University for their support of this study.

\section{Funding:}

This work was supported by postdoctoral scientific research developmental fund of Heilongjiang Province (LBH-Q20067), the National Key Research and Development Program of China (No. 2018YFD0200407).

\section{Competing Interests:}

The authors declare that we have no known competing financial interests or personal relationships that could have appeared to influence the work reported in this paper. The authors have no relevant financial or non-financial interests to disclose.

\section{Author Contributions:}

All authors contributed to the study conception and design. Liu Chunzhu: Data curation, Writing-original draft, Visualization, Investigation. Zhu Yingxue: Conceptualization, Methodology, Writing-review \& editing, Software. Wang Qi: Formal analysis. Xu Lianzhou: Conceptualization, Methodology. Ma Xianfa: Writing- review \& editing, Funding acquisition. The first draft of the manuscript was written by Liu Chunzhu and all authors commented on previous versions of the manuscript. All authors read and approved the final manuscript.

\section{Data Availability:}

The datasets generated during and/or analysed during the current study are available from the corresponding author on reasonable request.

\section{References}

1. Akhtar K, Wang WY, Ren GX, Khan A, Enguang N, Khan A, Feng YZ, Yang GH, Wang HY (2020) Straw mulching with inorganic nitrogen fertilizer reduces soil $\mathrm{CO}_{2}$ and $\mathrm{N}_{2} \mathrm{O}$ emissions and improves wheat yield. Science of the Total Environment, 741: 140188. https: //doi. Org/10.1016/j.scitotenv.2020.140488

2. Bradford MA, Wieder, William R (2016) Managing uncertainty in soil carbon feedbacks to climate change. Nature Climate Change, 6 (8): 751-758. https: //doi. Org/10.1038/NCLIMATE3071

3. Chen H, Luo P, Wen L, Yang L, Wang K, Li D (2017) Determinants of soil extracellular enzyme activity in a karst region, southwest China. European Journal of Soil Biology, 80: 69-76. https: //doi. Org/10.1016/j.ejsobi.2017.05.001

4. Chen J, Elsgaard L, Groenigen KJ, Olesen JE, Liang Z, Jiang Y, Lærke PE, Zhang YF, Luo YQ, Hungate BA, Sinsabaugh RL, Jørgensen U (2020) Soil carbon loss with warming: New evidence from carbon-degrading enzymes. Global Change Biology, 26(4): 1944-1952. https: //doi. Org/10.1111/gcb.14986

5. Chen RR, Senbayram M, Blagodatsky S, Myachina O, Dittert K, Lin XG, Blagodatskaya E, Kuzyakov Y (2014) Soil C and N availability determine the priming effect: microbial $\mathrm{N}$ mining and stoichiometric decomposition theories. Global Change Biology, 20(7): 2356-2367. https: //doi. Org/10.1111/gcb.12475

6. Elzobair KA, Stromberger ME, Ippolito JA (2016) Stabilizing effect of biochar on soil extracellular enzymes after a denaturing stress. Chemosphere, 142: 114-119. https: //doi. Org/10.1016/j.chemosphere.2015.03.018 
7. Gu BJ, Ge Y, Ren Y, Xu B, Luo WD, Jiang H, Gu BH, Chang J (2012) Atmospheric Reactive Nitrogen in China: Sources, Recent Trends, and Damage Costs. Environmental Science \& Technology, 46(17), 9420-9427. https: //doi. Org/10.1021/es301446g

8. Hagin J, Olsen SR, Shaviv A (1990) Review of interaction of ammonium-nitrate and potassium nutrition of crops. Journal of Plant Nutrition, 13(10): 1211-1226. https: //doi. Org/10.1080/01904169009364147

9. Hayes F, Lloyd B, Mills G, Jones L, Dore AJ, Carnell E, Viene M, Dise N, Fenner N (2019) Impact of long-term nitrogen deposition on the response of dune grassland ecosystems to elevated summer ozone. Environ. Pollut. 253, 821e830. https: //doi. Org/10.1016/j.envpol.2019.07.088

10. Herrera J, Rubio G, Häner L, Delgado J, Lucho-Constantino C, Islas-Valdez S, Pellet D (2016) Emerging and established technologies to increase nitrogen use efficiency of cereals. Agronomy-Basel 6(2): 25. https: //doi.

Org/10.3390/agronomy6020025

11. Huang S, Lv WS, Bloszies S, Shi QH, Pan XH, Zeng YJ (2016) Effects of fertilizer management practices on yield scaled ammonia emissions from croplands in China: A meta-analysis. Field Crop Res 192: 118-125. https: //doi.

Org/10.1016/j.fcr.2016.04.023

12. Ladha JK, Tirol-padre A, Reddy CK, Cassman KG, Verma S, Powlson DS, Kessel C, Richter DB, Chakraborty D, Pathak P (2016) Global nitrogen budgets in cereals: A 50-year assessment for maize, rice and wheat production systems. Scientific Reports, 6(1): 153-226. https: //doi. Org/10.1038/srep19355

13. Lan T, Li MX, Han Y, Deng OP, Tang XY, Luo L, Zeng J, Chen GD, Yuan S, Wang CQ, Gao XS (2020) How are annual $\mathrm{CH}_{4}, \mathrm{~N}_{2} \mathrm{O}$, and NO emissions from rice-wheat system affected by nitrogen fertilizer rate and type?. Applied Soil Ecology, 150: 103469. https: //doi. Org/10.1016/j.apsoil.2019.103469

14. Lasisi AA, Akinremi OO, Kumaragamage D (2021) Efficiency of fall versus spring applied urea-based fertilizers treated with urease and nitrification inhibitors II. Crop yield and nitrogen use efficiency. Soil Science Society of America Journal, 85(2): 299313. https: //doi. Org/10.1002/saj2.20126

15. Liang B, Yang XY, He XH, Murphy DV, Zhou JB (2012) Long-term combined application of manure and NPK fertilizers influenced nitrogen retention and stabilization of organic C in Loess soil. Plant and Soil, 353(1-2):249-260. https: //doi. Org/10.1007/s11104-011-1028-z

16. Li GH, Lin JJ, Xue LH, Ding YF, Wang SH, Yang LZ (2018) Fate of basal N under split fertilization in rice with ${ }^{15} \mathrm{~N}$ isotope tracer. Pedosphere, 28(1): 135-143. https: //doi. Org/10.1016/s1002-0160(17)60407-7

17. Li XM, Ju J, Xia YQ, Qian XQ, Yan XY, Zhou W (2021) Effects of different nitrogen fertilizer types on $\mathrm{NH}_{3}$ volatilization from open-air vegetable fields. Journal of Agro-Environment Science, 40(06): 1337-1343.

https://kns.cnki.net/kcms/detail/12.1347.s.20210326.1512.002.html

18. Liu SW, Cheng J, Wang C, Chen J, Jin YG, Zou ZH, Li SQ, Niu SL, Zou JW (2018) Climatic role of terrestrial ecosystem under elevated $\mathrm{CO}_{2}$ : A bottom-up greenhouse gases bud-get. Ecology Letters, 21(1): 1108-1118. https: //doi. Org/10.1111/ele.13078

19. Liu P, Zhao HJ, Li Y, Liu ZH, Gao XH, Zhang YP, Sun M, Zhong ZW, Luo JF (2018) Corn yields with organic and inorganic amendments under changing climate. Nutrient Cycling in Agroecosystems, 111: 141-153. https: //doi. Org/10.1007/s10705018-9916-8

20. Liu Z, Rong Q, Zhou W, Liang G (2017) Effects of inorganic and organic amendment on soil chemical properties, enzyme activities, microbial community and soil quality in yellow clayey soil. Plos One, 2017, 12(3): e0172767. https: //doi. Org/10.1371/journal.pone.0172767

21. Min J, Sun HJ, Kronzucker HJ, Wang Y, Shi WM (2021) Comprehensive assessment of the effects of nitrification inhibitor application on reactive nitrogen loss in intensive vegetable production systems. Agriculture Ecosystems \& Environment. 307, 107227. https: //doi. Org/10.1016/j.agee.2020.107227

22. Mei KC, Cheng L, Zhang QF, Lin KM, Zhou JC, Zeng QX, Wu Y, Xu JG, Zhou JR, Chen YM (2020) Effects of dissolved organic matter from different plant sources on soil enzyme activities in subtropical forests. Chinese Journal of Plant Ecology, 44 (12): 1273-1284. https: //doi. Org/10.17521/cjpe.2020.0097

23. Okami M, Matsunaka H, Fujita M (2016) Analysis of yield-attributing traits for high-yielding wheat lines in southwestern Japan. Plant Production Science, 19(3): 360-369. https: //doi. Org/10.1080/1343943X.2016.1151331 
24. Pant PK, Ram S, Singh V (2017) Yield and soil organic matter dynamics as affected by the long-term use of organic and inorganic fertilizers under rice-wheat cropping system in subtropical mollisols. Agricultural Research, 6(4):399-409. https: //doi. Org/ 10.1007/s40003-017-0282-6

25. Rashid M, Rafique H, Roshan S, Shamas S, Iqbal Z, Ashraf Z, Abbas Q, Hassan M, Qureshi ZUR, Asad MHHB, Dammak M (2020) Enzyme Inhibitory Kinetics and Molecular Docking Studies of Halo-Substituted Mixed Ester/Amide-Based Derivatives as Jack Bean Urease Inhibitors. BioMed Research International, 2020-2029. https: //doi. Org/10.1155/2020/8867407

26. Redding MR, Lewis R, Kearton T, Smith $O$ (2016) Manure and sorbent fertilisers increase on-going nutrient availability relative to conventional fertilisers. Science of the Total Environment, 569/570: 927-936. https: //doi.

Org/10.1016/j.scitotenv.2016.05.068

27. Saiya-Cork KR, Sinsabaugh RL, Zak DR (2002) The effects of long term nitrogen deposition on extracellular enzyme activity in an Acer saccharum forest soil. Soil Biology \& Biochemistry, 34, 1309-1315. https: //doi. Org/10.1016/s0038-0717(02)00074-3

28. Shan LN, He YF, Chen J, Huang Q, Wang HC (2015) Ammonia volatilization from a Chinese cabbage field under different nitrogen treatments in the Taihu Lake Basin, China. Journal of Environmental Sciences, 38: 14-23. https: //doi.

Org/10.1016/j.jes.2015.04.028

29. Shang QY, Gao CM, Yang XX, Wu PP, Ling N, Shen QR, Guo SW (2014) Ammonia volatilizationin Chinese double rice-cropping systems: A 3-year field measurement in longterm fertilizer experiments. Biology and Fertility of Soils, 50(5): 715-725. https: //doi. Org/10.1007/s00374-013-0891-6

30. Sinsabaugh RL, Shah JJF (2012) Ecoenzymatic stoichiometry and ecological theory. Annual Review of Ecology, Evolution, and Systematics, 43: 313-343. https: //doi. Org/10.1146/annurev-ecolsys-071112-124414

31. Thomsen IK, Christensen B (1998) Cropping system and residue management effects on nitrate leaching and crop yields. Agriculture Ecosystems and Environment, 68(1): 73-84. https: //doi. Org/10.1016/s0167-8809(97)00134-5

32. Ti C, Xia L, Chang SX, Yan XY (2019) Potential for mitigating global agricultural ammonia emission: A meta-analysis. Environmental Pollution, 245: 141-148. https: //doi. Org/10.1016/j.envpol.2018.10.124

33. Van ZL, Singh BP, Kimber SWL, Murphy DV, Macdonald LM, Rust J, Morris S (2014) An incubation study investigating the mechanisms that impact $\mathrm{N}_{2} \mathrm{O}$ flux from soil following biochar application. Agriculture Ecosystems \& Environment, 191(11): 5362. https: //doi. Org/10.1016/j.agee.2014.02.030

34. Vinzent B, Fuß R, Maidl FX, Hülsbergen KJ (2017) Efficacy of agronomic strategies for mitigation of after-harvest $\mathrm{N}_{2} \mathrm{O}$ emissions of winter oilseed rape. European Journal of Agronomy, 89, 88-96. https: //doi. Org/10.1016/j.eja.2017.06.009

35. Wang DY, Xu CM, Ye C, Chen S, Chu G, Zhang X (2018) Low recovery efficiency of basal fertilizer-N in plants does not indicate high basal fertilizer-N loss from split-applied $\mathrm{N}$ in transplanted rice. Field Crops Research, 229: 8-16. https: //doi.

Org/10.1016/j.fcr.2018.09.008

36. Wang F, Li J, Wang X, Zhang W, Zou B, Neher DA, Li Z (2014) Nitrogen and phosphorus addition impact soil $\mathrm{N}_{2} \mathrm{O}$ emission in a secondary tropical forest of South China. Scientific reports, 4: 35-42. https: //doi. Org/10.1038/srep05615

37. Wen X, Hu CX, Sun XC, Zhao XH, Tan QL (2019) Research on the nitrogen transformation in rhizosphere of winter wheat (Triticum aestivum) under molybdenum addition. Springer Berlin Heidelberg, 26(3): 2363-2374. https: //doi. Org/10.1007/s11356-018-3565-y

38. Xia LL, Lam SK, Yan XY, Chen D (2017) How does recycling of livestock manure in agroecosystems affect crop productivity, reactive nitrogen losses and soil carbon balance. Environmental Science \& Technology, 51(13): 7450-7457. https: //doi. Org/10.1021/acs.est.6b06470

39. Zamanian K, Kuzyakov Y (2019) Contribution of soil inorganic carbon to atmospheric $\mathrm{CO}_{2}$ : more important than previously thought. Global change biology, 25(1): e1-e3. https: //doi. Org/10.1111/gcb.14463

40. Zhai H, Liu H, Zhang J, Huang J, Wang B (2011) Long-term application of organic manure and mineral fertilizer on $\mathrm{N}_{2} \mathrm{O}$ and $\mathrm{CO}_{2}$ emissions in a red soil from cultivated maize-wheat rotation in China. Agriculture science in China, 10, 1748-1757. https: //doi. Org/10.1016/S1671-2927(11)60174-0

41. Zhao J, Ni T, Li J, Lu Q, Fang ZY, Huang QW, Zhang RF, Li R, Shen B, Shen Q (2016) Effects of organic-inorganic compound fertilizer with reduced chemical fertilizer application on crop yields, soil biological activity and bacterial community structure in 
a rice-wheat cropping system. Applied soil ecology, 99: 1-12. https: //doi. Org/10.1016/j.apsoil.2015.11.006

42. Zhou W, Tian YH, Yin B (2011) Ammonia volatilization and nitrogen balance after topdressing fertilization in paddy fields of

Taihu Lake region. Chinese Journal of Eco-Agriculture, 19 (1): 32-36. https: //doi. Org/10.3724/SP.J.1011.2011.00032

43. Zhou BY, Sun XF, Ding ZS, Ma W, Zhao M (2017) Multisplit nitrogen application via drip irrigation improves maize grain yield and nitrogen use efficiency. Crop Science, 57(3): 1 687-1 703. https: //doi. Org/10.2135/cropsci2016.07.0623

Figures
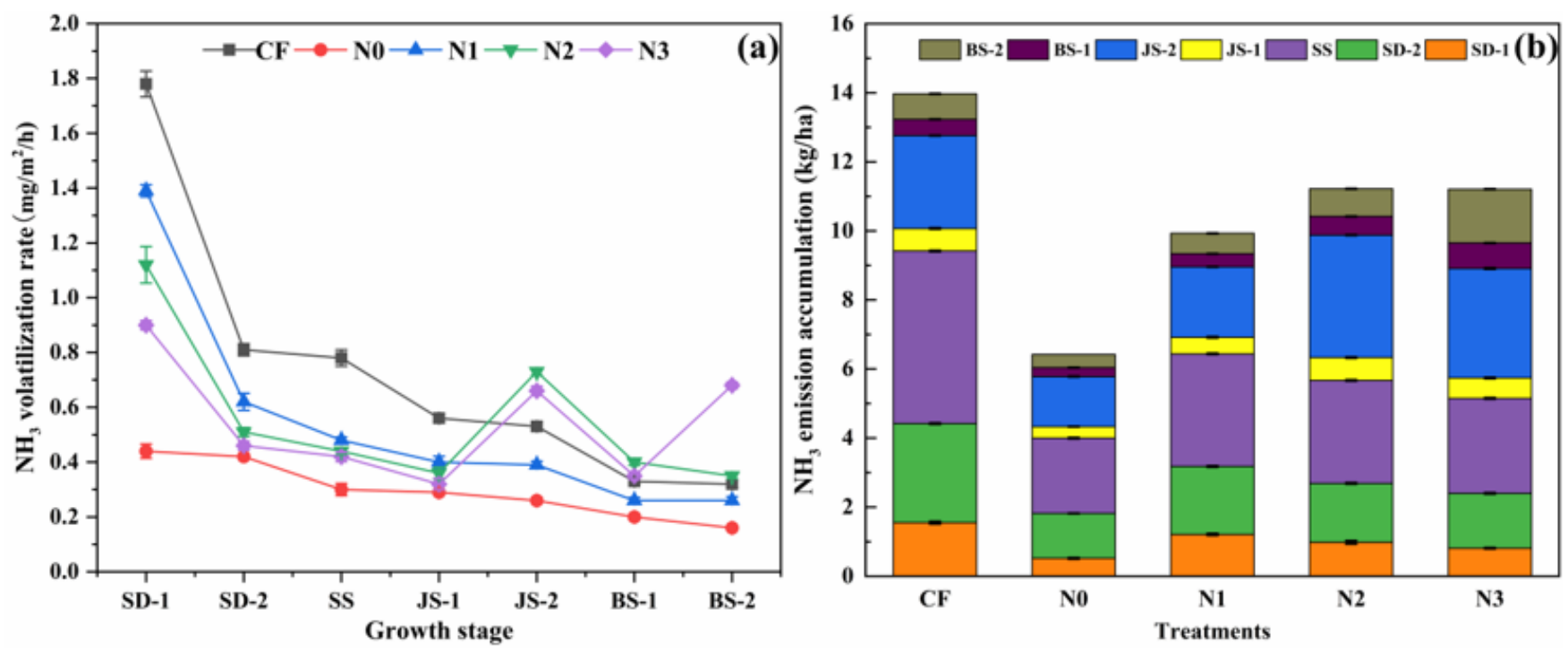

Figure 1

Substitute organic fertilizer for chemical fertilizer and fertilization with stage application method affected (a) $\mathrm{NH}_{3}$ volatilization rate and (b) $\mathrm{NH}_{3}$ volatilization accumulation during wheat growth.

Note: growth stage; SD-1, the third day after fertilization; SD-2, the eighth day after fertilization; SS, seeding stage; JS-1, before jointing stage fertilization; JS-2, after jointing stage fertilization; BS-1, before booting stage fertilization; BS-2, after booting stage fertilization; The same below.
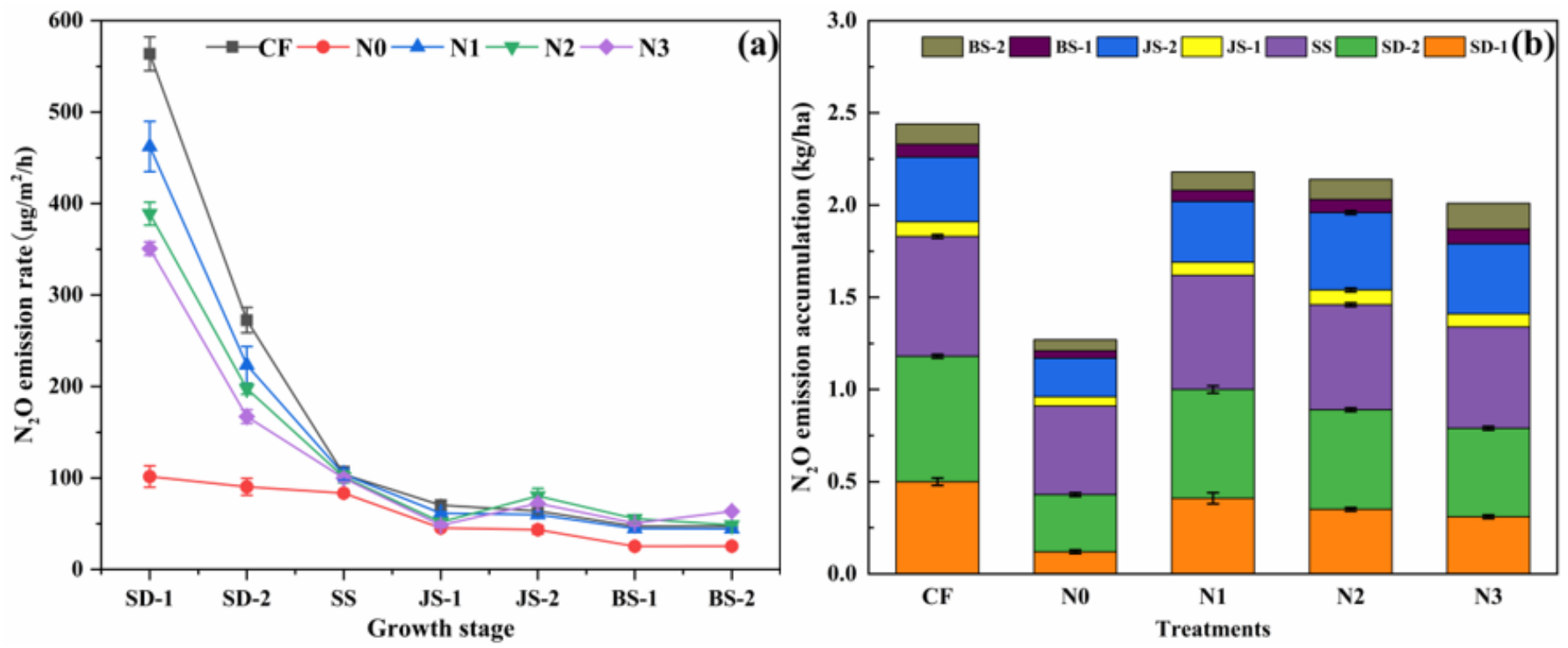
Figure 2

Substitute organic fertilizer for chemical fertilizer and fertilization with stage application method affected (a) $\mathrm{N}_{2} \mathrm{O}$ emission rate and (b) $\mathrm{N}_{2} \mathrm{O}$ emission accumulation during wheat growth.
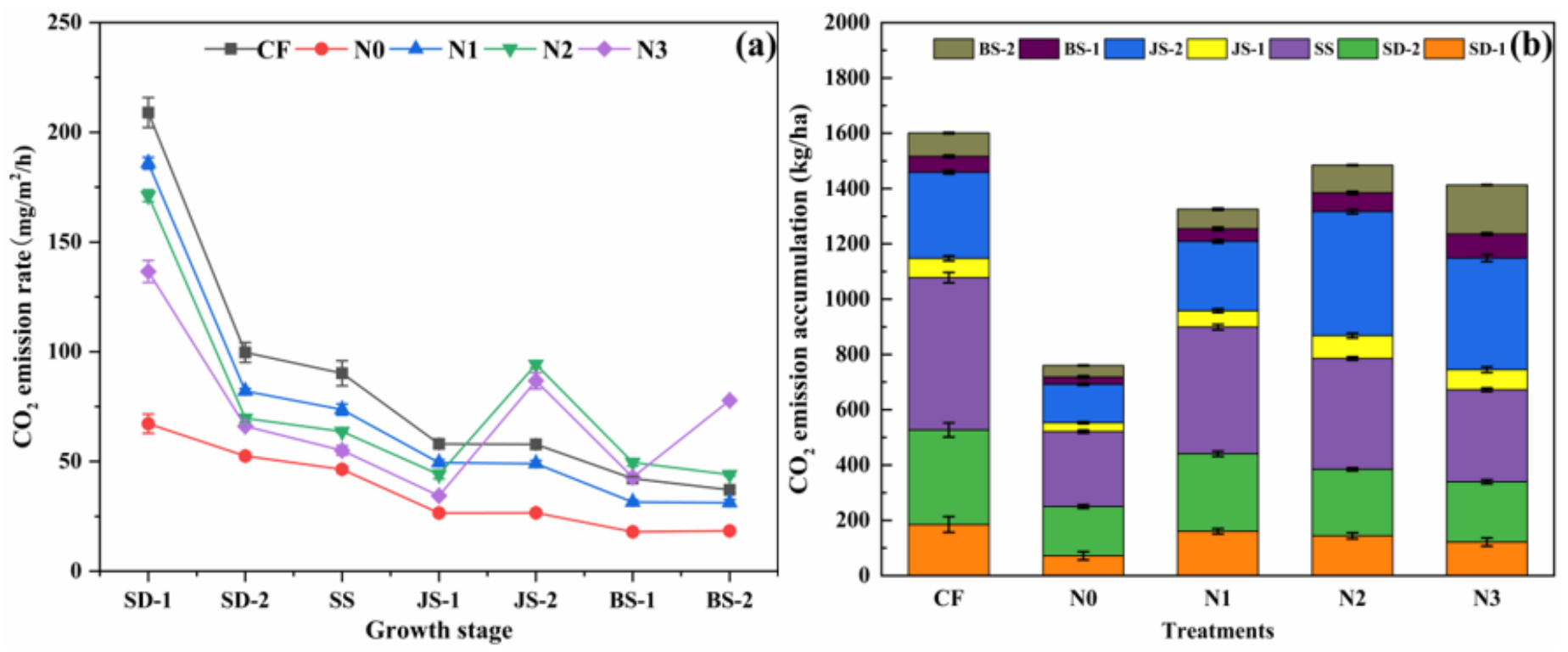

Figure 3

Substitute organic fertilizer for chemical fertilizer and fertilization with stage application method affected (a) $\mathrm{CO}_{2}$ emission rate and (b) $\mathrm{CO}_{2}$ emission accumulation during wheat growth. 

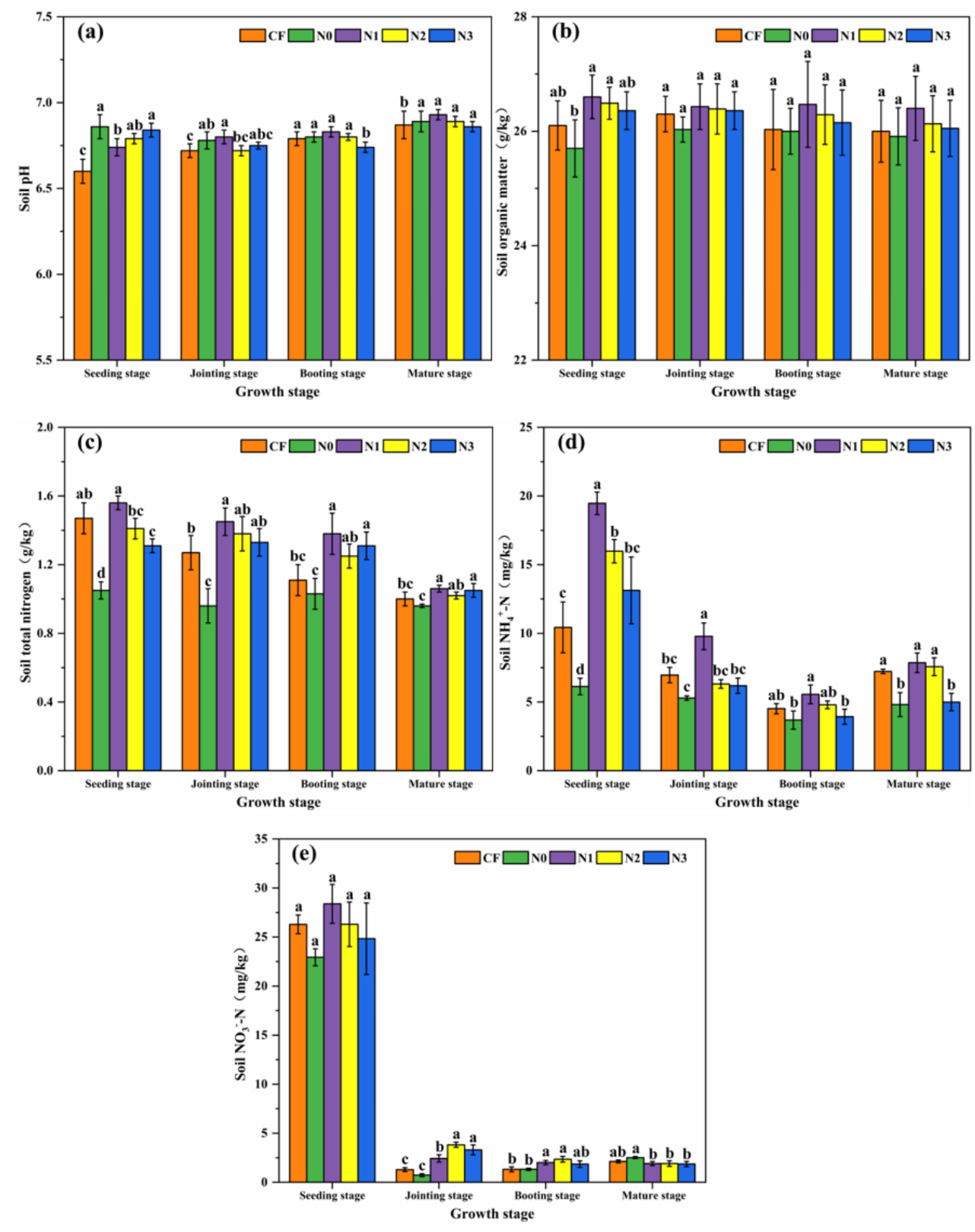

Figure 4

Changes of (a) soil pH, (b) soil organic matter, (c) soil total nitrogen, (d) soil $\mathrm{NH}_{4}{ }^{+}-\mathrm{N}$ and (e) soil $\mathrm{NH}_{4}{ }^{+}-\mathrm{N}$ in spring wheat fields under the different nitrogen fertilizer managements. 

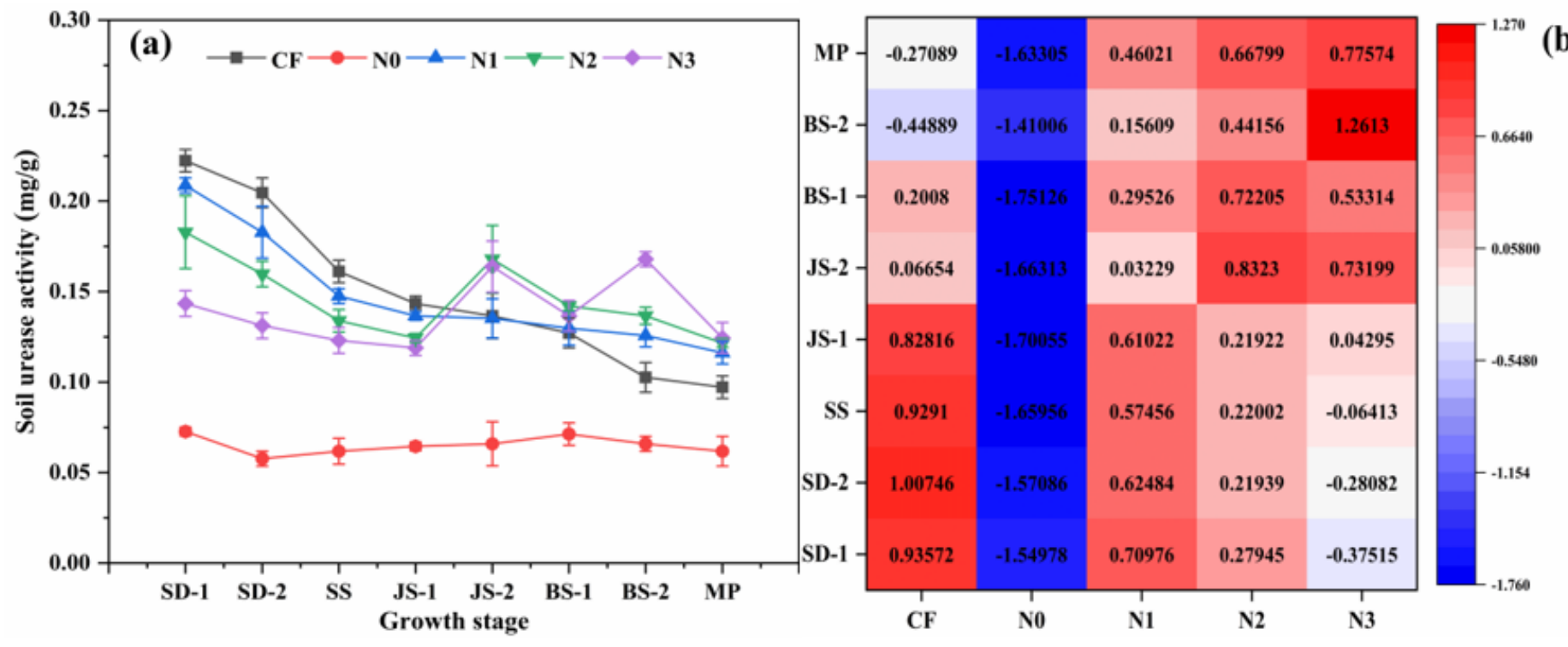

\section{Figure 5}

(a) Changes in soil urease activity in different growth stages of wheat, (b) Heat map analysis of soil urease activity in different treatments.
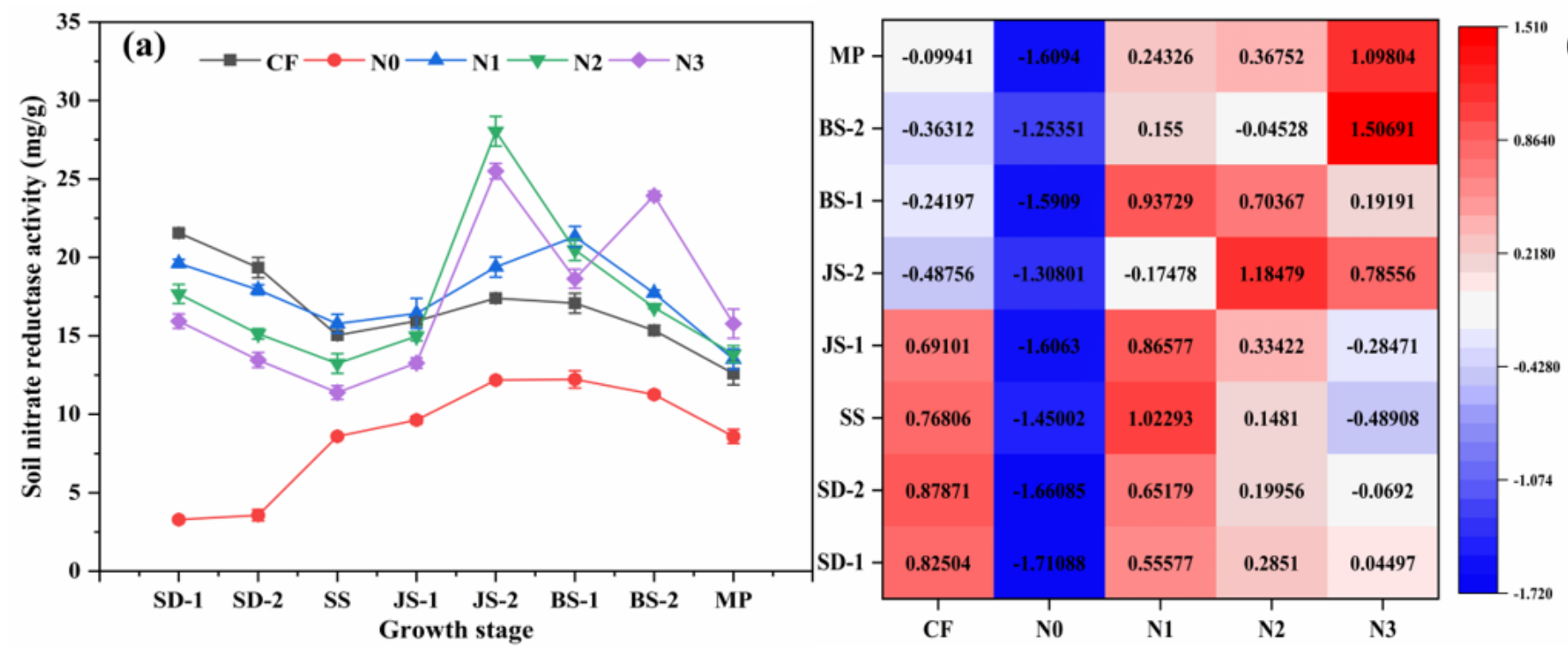

\section{Figure 6}

(a) Changes in soil nitrate reductase activity in different growth stages of wheat, (b) Heat map analysis of soil nitrate reductase activity in different treatments. 

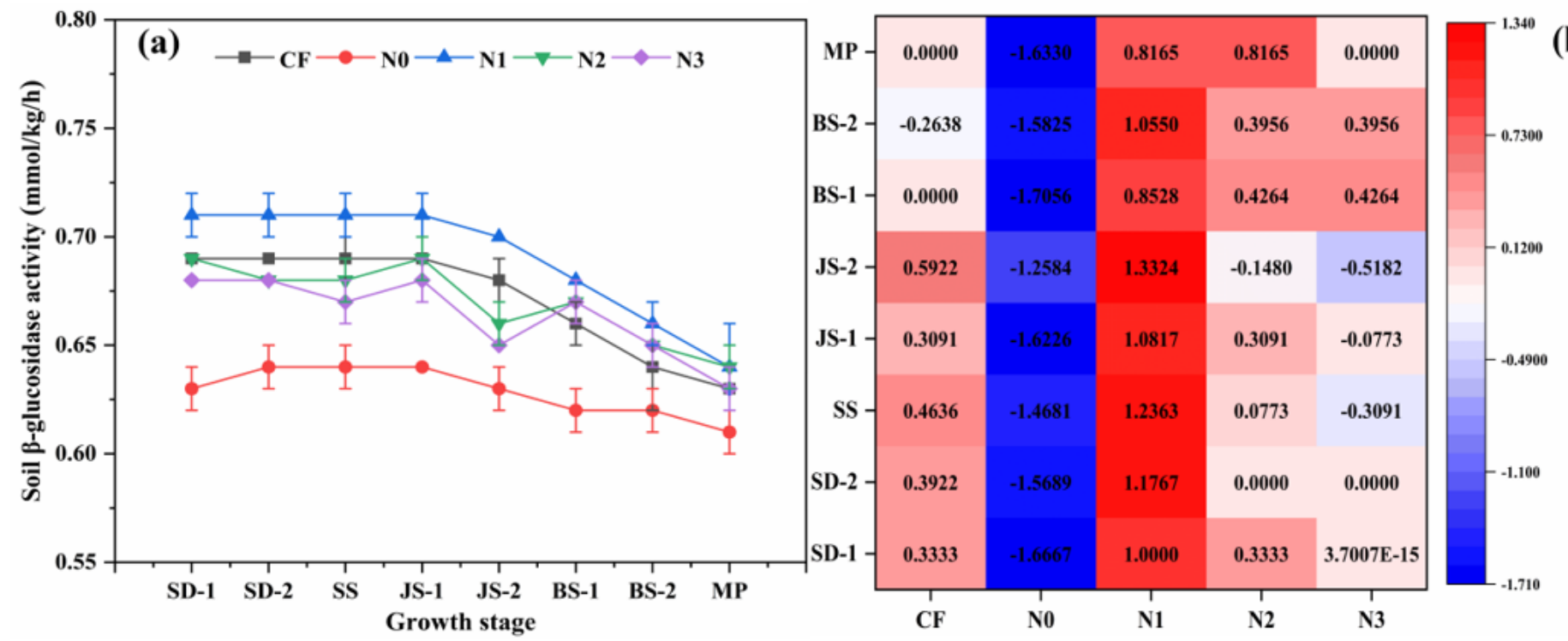

(b)
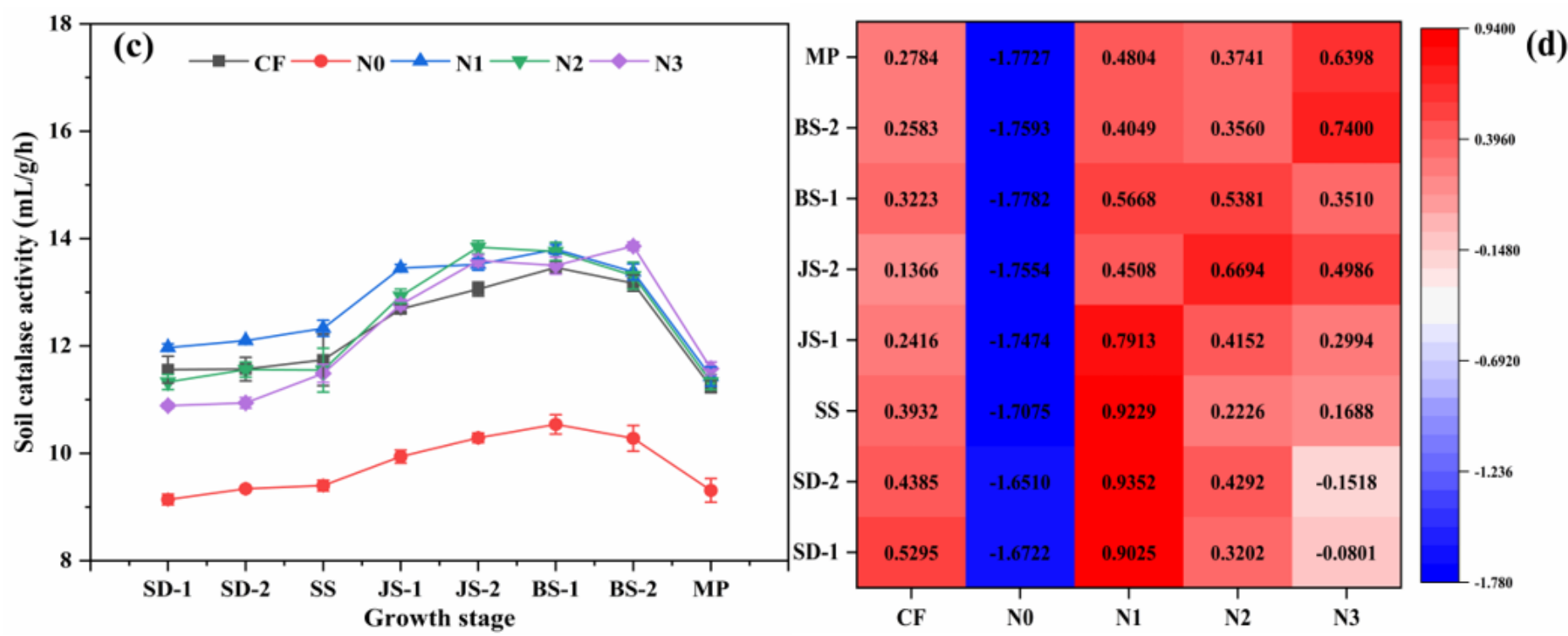

Figure 7

(a) Changes in soil $\beta$-glucosidase activity in different growth stages of wheat, (b) Heat map analysis of soil $\beta$-glucosidase activity in different treatments, (c) Changes in soil catalase activity in different growth stages of wheat and (d) Heat map analysis of soil catalase activity in different treatments. 